\title{
An empirical analysis of sectoral indices movement in Malaysian stock market
}

\author{
Jaafar Pyeman \\ Ismail Ahmad \\ Arshad Ayub Graduate Business School, \\ Faculty of Business and Management, UiTM Shah Alam, Malaysia
}

\begin{abstract}
Keywords
Vector Error Correction Model; Vector Auto regression Model; Macroeconomic Variable; Sectoral Indices
\end{abstract}

\begin{abstract}
The aim of this study is to investigate the dynamic movement between sectoral indices in the Malaysian Stock Market and the three macroeconomic variables, namely oil price (OP), gold price (GP), and exchange rate (ER) during the period 1995-2014. Using the Augmented DickeyFuller and Phillip Perron unit root test, the underlying series are tested as non-stationary at the level but stationary in first difference. The use of Johansen-Juselius (1990) Multivariate Cointegration and Vector Error Correction Model indicate that there is long run linkages between macroeconomic variable and sectoral indices specifically in Technology sector. Meanwhile, the analysis based on Vector Auto regression Model technique indicates that there are short run linkages between macroeconomic variable and sectoral indices namely Financial, Industrial, Consumer Product, Industrial Product, Properties and Trade and Service.
\end{abstract}

Corresponding author: Jaafar Pyeman

Email address for corresponding author: jaaf@salam.uitm.edu.my

First submission received: 15th February 2017

Revised submission received: 25th March 2017

Accepted: 7th April 2017

\section{Introduction}

The financial market was globally affected due to the several crises such as financial crisis that happened in year 2007 and 2008, debt crisis in Greece, credit crisis and China's market crash. However, there was a main concern regarding this financial crisis issue which is the volatility of the stock market changes. Understanding the volatility of stock market is deemed crucial to determine the cost of capital and to assess investment and leverage decisions as volatility is perceived as a risk. Hence, stock market has become an important tool in developing and sustaining capital formation and economic growth in Malaysia.

Several studies in Malaysia as well as other countries have been conducted on the linkages between macroeconomic variable with stock market (Joshi and Giri, 2013;Asaolu and Ogunmuyiwa, 2011;Zhao, 2010; Rahman, Sidek and Tafri, 2009; Jaafar and Ismail (2009); Maysami, Howe and Hamzah, 2004; Hosseini, Ahmad and Lai, 2011). Most of the studies could be further enhanced by exploring the linkages between stock market as represented by sectoral indices instead of aggregate stock index and macroeconomic variables.As a developing country, Malaysia has a lot to offer in terms of its ever-changing macroeconomic variables. Understanding the linkages between the selected variables (crude oil price, gold price and exchange rate) is important for this study. This is because as developing economies like Malaysia continues to grow and prosper, they will exert a larger influence on the global economy. Mohamed, Ali, Abdullah and Azman (2011) concurs that the dramatic changes in all sectors of Bursa Malaysia were due to globalization and liberalization concept that is applied by Malaysian government have influence the stock return. They also 
mentioned that the performance of companies listed in the Main Market fluctuated based on the market condition and have affected several factors such as economic, financial, business and liquidity.

\section{Linkages between Stock Market Movement and Macroeconomic Variables (Gold Price, Oil Price and Exchange Rate)}

Gold has been a part of economic life in many cultures and generations. As an asset, it tends to be particularly attractive during period of economic uncertainty or politically instability. Due to unstable world markets, there is an increasing interest in gold. Some financial theories argued that gold could be considered as a safe investment when the economic environment is uncertain. When other investments are decreasing, gold usually increase. Gold is mostly considered as independent from other factors, and therefore it is believed that it is low correlated with stock, Baur and Lucey (2010).

Meanwhile, the growing of global economy, increase in mass production and world trade together with the vast usage of technology, puts oil in a very special position (Masih, Peters and De Mello,2011). The fluctuation of oil price will increase and decrease market's assurance with its direct effect on production costs (Park and Ratti, 2008; Fatima and Bashir, 2014). According to Gencer and Demiralay (2014), there are two channels whereby the business activity level is highly influenced by oil price movements and impacts the stock price which (1) the business earnings and cash flows are directly affected by oil prices and (2) investor's required rate return is determined as a result of inflation, risk and interest rates. With the current instability of oil price, it is now quite apt to add research on the impact of oil price toward equity return. Through the various studies conducted, there were mixed results. Some studies show a positive relation, some negative and some no significant relation.

On the other hand, the strong linkages between stock prices and exchange rates have been well liked among many people (Phylaktis, Kate, Ravazzolo and Fabiola, 2005; Jaafar and Ismail, 2009). The linkages between both variables have also been the focus for many researchers in doing empirical analysis. According to Kalyanaraman and Al Tuwajri (2014), good market approach and portfolio balance approach are the two methods in evaluating the linkages between variables, stock prices and exchange rate. Singh (2015) mentioned that goods market approach (flow oriented) that was initially examined by Dornbusch and Fisher, hypothesized that the movement of exchange rate caused movement in stock price. Pan, Fok and Liu (2007) examined the dynamic linkages between exchange rate and stock prices for seven East Asian countries and their empirical results showed that there is significant causal relation from exchange rate to stock prices for some countries including Japan, Malaysia and Thailand before the Asian financial crisis. A study by Wongbangpo and Sharma (2002) on 5 ASEAN countries reveals that exchange rate has a positive relation to stock prices in Indonesia, Malaysia and Philippines, however, has a negative relation with Singapore and Thailand. Furthermore, the mixed influence of exchange rates on the sectoral indices movements are also observed in the previous studies (Ibrahim, 2000; Jaafar and Ismail, 2009).

Therefore, the aim of this paper is to provide further understanding in terms of the linkages between sectoral indices movement in Bursa Malaysia especially from both long run and short run perspectives with the changes in macroeconomic variables namely crude oil price (OP), gold price (GP) and exchange rate (ER). It is hope that it will be beneficial to the investors, portfolio managers, and market members as they can determine the performance and behaviors of stock price. With the forecast on market prices together with well diversified investment portfolio, it can help the investors to minimize the risks as well as increase the future return in the market.

\section{Problem Statement}

In Malaysia, the Stock Market (known locally as the Bursa Malaysia) plays an important role in nourishing capital formation and sustaining the economic growth. It does not only comprise of gathering and transferring funds and capital, but it also shares the risks. Investors face the highest 
risk when investing in the stock market compared to other form of financial investment such as bond, Treasury bill and fixed deposit as stock or equity investment is considered sensitive to the changes in investment environment particularly from macroeconomic perspective. Specifically, changes in macroeconomic variables have contributed certain impact on equity performance as represented by different responses (magnitude and direction) of the sectoral indices movement in Bursa Malaysia (Jaafar and Ismail, 2009). The movements in sectoral indices reflect the performance of the stock price according to the respective sectors in Bursa Malaysia. The fluctuation of stock prices are almost every second and the changes in prices have been partly influenced by the changes in macroeconomic variables such as gold prices, oil prices and exchange rate. In this regards, it is very crucial and critical for the investors to know about the dynamic movement between stock price performances as represented by sectoral indices movement in relation in response to the changes in macroeconomic variables (Fedorova and Pankratov, 2010; Khan and Zaman, 2011; Jaafar and Ismail, 2009). On that note, there are limited studies devoted towards the sectoral indices analysis in relation to the changes in macroeconomic variables. Previous studies were mainly focusing on the linkages between average composite index of the stock market instead of sectoral indices as the proxy in relation to the changes in macroeconomic variables. Thus, due to limited information regarding the analysis on sectoral indices movement, this study investigates the long run and short run linkages between the selected macroeconomic variables (crude oil, gold price and exchange rate) and ten sectoral indices of Bursa Malaysia (Construction, Consumer Product, Industrial Production, Trading/Services, Technology, Finance, Properties, Plantation, Mining and Industrial). The findings from this analysis are not only provide more information to the investors with regard the direction of the sectoral indices future movement but it could also become useful guideline for them to effectively strategize their investment activities particularly in selecting the stock from various sectors in establishing well diversified portfolio of stock investment.

\section{Data and Methodology}

This paper focuses on 10 sector specific indices (Construction, Consumer Product, Industrial Production, Trading/Services, Technology, Finance, Properties, Plantation, Mining and Industrial) and 3 macroeconomic variables (gold price, crude oil price and exchange rate). The data was obtained from Datastream, World Gold Council, Worldbank and International Financial Statistic respectively based on monthly basis from January 1995 to December 2014 with a total of 240 monthly observations. There are several tests have been conducted to investigate the linkages between macroeconomic variables with sectoral indices namely Unit Root Test, Johansen Cointegration, Vector Error Correction Model (VECM) and Vector Autoregression (VAR).

The brief description of each variable used is presented in Table 1 below.

\begin{tabular}{|l|l|l|ll|}
\hline Variables & Description & Units & Source of Data \\
\hline Sectoral Indices & Composite market index in Malaysia & Index & Data stream \\
\hline Gold Price & Unit per troy ounce & USD & World Gold Council \\
\hline Crude Oil Price & Dated Brent price per barrel & USD & World bank \\
\hline Exchange Rate & $\begin{array}{l}\text { Value of 1 U.S. Dollar in Malaysian } \\
\text { Ringgits }\end{array}$ & RM & $\begin{array}{l}\text { International Financial } \\
\text { Statistic }\end{array}$ \\
\hline
\end{tabular}

\section{Table 1: Data description}

\section{Results and discussions Unit Root Test}

The issue of the stability of the data is very important to be determined at the early stage of the data analysis as it will affect the findings which will be reported at the end of the analysis. This paper provides a significant consideration regarding the stability of the data in leading towards producing reliable and justified findings which could represent the overall scenario of the situation regarding the linkages between sectoral indices movements and changes in macroeconomics 
variables namely oil price, gold price and exchange rate. The results of the stationarity test based on Augmented Dickey-Fuller and Phillips-Perron are shown in Table 2 below.

\begin{tabular}{|c|c|c|c|c|}
\hline \multirow[t]{2}{*}{ Variables } & \multicolumn{2}{|l|}{ ADF } & \multicolumn{2}{|l|}{ PP } \\
\hline & Level & 1st Diff. & Level & 1st Diff. \\
\hline \multicolumn{5}{|c|}{ Sectoral Indices } \\
\hline FIN & -1.788012 & $-13.59859^{* * *}$ & -2.159295 & $-13.83876^{* * *}$ \\
\hline CONSTR & -2.194709 & $-12.57312^{* * *}$ & -2.207325 & $-12.61909^{* * *}$ \\
\hline IND & -2.059837 & $-14.84716^{* * *}$ & -2.192713 & $-14.86092^{* * *}$ \\
\hline CONSPRO & -1.46517 & $-14.60678^{* * *}$ & -1.566846 & $-14.66281^{* * *}$ \\
\hline INDPRO & -2.30984 & $-12.30046^{* * *}$ & -1.75736 & $-12.2651^{* * *}$ \\
\hline PLANT & -2.311269 & $-13.15414^{* * *}$ & -2.30096 & $-13.17597^{* * *}$ \\
\hline PROPER & -1.767163 & $-13.94071^{* * *}$ & -1.92969 & $-14.01214^{* * *}$ \\
\hline $\mathrm{TECH}$ & -9.077946 & $-10.8693^{* * *}$ & $-7.523257^{* * *}$ & $-11.42466^{* * *}$ \\
\hline TIN & -2.898853 & $-16.45741^{* * *}$ & -2.943868 & $-16.45426^{* * *}$ \\
\hline TRADE & -2.313604 & $-13.33381^{* * *}$ & -1.92658 & $-13.3018^{* * *}$ \\
\hline \multicolumn{5}{|c|}{ Economic Indicators } \\
\hline GOLD & -1.696665 & $-18.41776^{* * *}$ & -1.810945 & $-18.55298^{* * *}$ \\
\hline OIL & $-3.21881^{*}$ & $-9.539614^{* * *}$ & -2.912781 & $-9.589793^{* * *}$ \\
\hline XCHNGE & -2.207027 & $-12.64244^{* * *}$ & -2.071746 & $-12.54382^{* * *}$ \\
\hline
\end{tabular}

\section{Table 2: Unit Root Test Result}

The application of unit root test analysis is important as both ADF and Philip-Perron tests could be used to confirm the data whether it have unit root or not. The series of the data has been analyzed based on its level according to ADF test and it indicates that the series are non-stationary. The findings have been found to be different as it become stationary when the series of data being converted into first difference. The stationarity of the series of data is found to be at $1 \%$ significant level. On the other hand, the similar findings have also been found that the data series after it has been converted into first difference to become stationary at $1 \%$ significant level based on the PhilipPerron tests. It seems that all data series are in good condition to be analyzed based on the findings which have been obtained from both ADF and Philip-Perronstationarity test.

\section{Johansen Cointegration Test}

The analysis on the linkages between sectoral indices and macroeconomic variables has been analyzed based on its integration at the same level as indicated in the finding from stationarity analysis in the previous section. Generally, the linkages between the variables have been observed in both long term as well short term. Thus, the linkages or cointegration between the data series can be empirically proven and observed during the 20 years trend. Specifically, Johansen and Juselius (1990) Cointegration test has been applied in the analysis in order to confirm the long run linkages between the data series during the 20 years of observation. The critical p-value of statistic of $1 \%$ has been used as a guideline in confirming the long run linkages between the data series based on various economic performance. The results from Johansen and Juselius Cointegration test for different market sector has been obtained as presented in Table 3 below. 
Journal of Business and Retail Management Research (JBRMR), Vol. 11 Issue 4

\begin{tabular}{|c|c|c|c|c|c|c|}
\hline \multirow{2}{*}{$\begin{array}{l}\text { Sectoral } \\
\text { Indices }\end{array}$} & Hypothesized & \multirow[b]{2}{*}{ Eigenvalue } & Trace & 0.05 & Max-Eigen & 0.05 \\
\hline & No. of CE(s) & & Statistic & $\begin{array}{l}\text { Critical } \\
\text { Value }\end{array}$ & Statistic & $\begin{array}{l}\text { Critical } \\
\text { Value }\end{array}$ \\
\hline \multirow{4}{*}{ Financial } & $r=0$ & 0.101460 & $45.47817^{*}$ & 47.85613 & 25.14138 & 27.58434 \\
\hline & $\mathrm{r} \leq 1$ & 0.056198 & 20.33679 & 29.79707 & 13.59203 & 21.13162 \\
\hline & $\mathrm{r} \leq 2$ & 0.026211 & 6.744758 & 15.49471 & 6.241825 & 14.26460 \\
\hline & $r \leq 3$ & 0.002138 & 0.502933 & 3.841466 & 0.502933 & 3.841466 \\
\hline \multirow{4}{*}{$\begin{array}{l}\text { Constructio } \\
\mathrm{n}\end{array}$} & $r=0$ & 0.066798 & 39.80648 & 47.85613 & 16.24638 & 27.58434 \\
\hline & $\mathrm{r} \leq 1$ & 0.053695 & 23.56010 & 29.79707 & 12.96966 & 21.13162 \\
\hline & $r \leq 2$ & 0.042612 & 10.59044 & 15.49471 & 10.23349 & 14.26460 \\
\hline & $r \leq 3$ & 0.001518 & 0.356950 & 3.841466 & 0.356950 & 3.841466 \\
\hline \multirow{4}{*}{ Industrial } & $r=0$ & 0.102606 & 40.27051 & 47.85613 & $25.44105^{*}$ & 27.58434 \\
\hline & $r \leq 1$ & 0.037440 & 14.82946 & 29.79707 & 8.967278 & 21.13162 \\
\hline & $r \leq 2$ & 0.024604 & 5.862184 & 15.49471 & 5.854340 & 14.26460 \\
\hline & $\mathrm{r} \leq 3$ & 3.34E-05 & 0.007844 & 3.841466 & 0.007844 & 3.841466 \\
\hline \multirow{4}{*}{$\begin{array}{l}\text { Consumer } \\
\text { Product }\end{array}$} & $r=0$ & 0.076624 & 39.81783 & 47.85613 & 18.73380 & 27.58434 \\
\hline & $\mathrm{r} \leq 1$ & 0.049404 & 21.08403 & 29.79707 & 11.90648 & 21.13162 \\
\hline & $\mathrm{r} \leq 2$ & 0.034337 & 9.177547 & 15.49471 & 8.210889 & 14.26460 \\
\hline & $r \leq 3$ & 0.004105 & 0.966658 & 3.841466 & 0.966658 & 3.841466 \\
\hline \multirow{4}{*}{$\begin{array}{l}\text { Industrial } \\
\text { Product }\end{array}$} & $r=0$ & 0.072170 & 35.85933 & 47.85613 & 17.60309 & 27.58434 \\
\hline & $r \leq 1$ & 0.040620 & 18.25624 & 29.79707 & 9.745028 & 21.13162 \\
\hline & $\mathrm{r} \leq 2$ & 0.030198 & 8.511216 & 15.49471 & 7.205977 & 14.26460 \\
\hline & $\mathrm{r} \leq 3$ & 0.005539 & 1.305239 & 3.841466 & 1.305239 & 3.841466 \\
\hline \multirow{4}{*}{ Plantation } & $r=0$ & 0.059411 & 27.24875 & 47.85613 & 14.39345 & 27.58434 \\
\hline & $\mathrm{r} \leq 1$ & 0.036659 & 12.85530 & 29.79707 & 8.776754 & 21.13162 \\
\hline & $\mathrm{r} \leq 2$ & 0.016642 & 4.078550 & 15.49471 & 3.943847 & 14.26460 \\
\hline & $\mathrm{r} \leq 3$ & 0.000573 & 0.134703 & 3.841466 & 0.134703 & 3.841466 \\
\hline \multirow{4}{*}{ Properties } & $r=0$ & 0.079391 & 39.89146 & 47.85613 & 19.43927 & 27.58434 \\
\hline & $\mathrm{r} \leq 1$ & 0.049067 & 20.45218 & 29.79707 & 11.82318 & 21.13162 \\
\hline & $\mathrm{r} \leq 2$ & 0.028949 & 8.629004 & 15.49471 & 6.903533 & 14.26460 \\
\hline & $\mathrm{r} \leq 3$ & 0.007316 & 1.725471 & 3.841466 & 1.725471 & 3.841466 \\
\hline \multirow{4}{*}{ Technology } & $\mathrm{r}=0$ & 0.155949 & $49.65300^{* *}$ & 47.85613 & $28.99179 * *$ & 27.58434 \\
\hline & $\mathrm{r} \leq 1$ & 0.061720 & 20.66121 & 29.79707 & 10.89383 & 21.13162 \\
\hline & $\mathrm{r} \leq 2$ & 0.048619 & 9.767377 & 15.49471 & 8.522825 & 14.26460 \\
\hline & $\mathrm{r} \leq 3$ & 0.007252 & 1.244552 & 3.841466 & 1.244552 & 3.841466 \\
\hline \multirow{4}{*}{$\begin{array}{l}\text { Tin } \\
\text { Mining }\end{array}$} & $r=0$ & 0.078073 & 37.54712 & 47.85613 & 19.10296 & 27.58434 \\
\hline & $\mathrm{r} \leq 1$ & 0.048165 & 18.44417 & 29.79707 & 11.60051 & 21.13162 \\
\hline & $r \leq 2$ & 0.028260 & 6.843655 & 15.49471 & 6.736649 & 14.26460 \\
\hline & $r \leq 3$ & 0.000455 & 0.107005 & 3.841466 & 0.107005 & 3.841466 \\
\hline \multirow{4}{*}{$\begin{array}{l}\text { Trade } \quad \& \\
\text { Service }\end{array}$} & $r=0$ & 0.077334 & 33.66470 & 47.85613 & 18.91456 & 27.58434 \\
\hline & $\mathrm{r} \leq 1$ & 0.039193 & 14.75015 & 29.79707 & 9.395793 & 21.13162 \\
\hline & $\mathrm{r} \leq 2$ & 0.019079 & 5.354354 & 15.49471 & 4.526814 & 14.26460 \\
\hline & $\mathrm{r} \leq 3$ & 0.003515 & 0.827540 & 3.841466 & 0.827540 & 3.841466 \\
\hline
\end{tabular}

\section{Table 3: Johansen Cointegration Test Result}

According to the analysis based on cointegration perspective, the finding has clearly shown that the long run linkages is found to be significant at $10 \%$ critical level particularly for the two sectors namely Finance, Industrial and 5\% critical level for Technology. This finding is consistent 
with both Trace and Max-Eigen value that indicates the significant linkages between the data series in the long run.

Hypothesis:

$H_{0}$ : Long-run linkages does not exist between variables.

$H_{1}$ : Long-run linkages exists between variables

Based on the results, we cannot reject the null hypothesis for almost all market sectors which means that almost all market sectors do not have long-run linkages between economic variables and stock indices. Only test statistics for technology sector indices indicate at most one cointegrating linkages, where we reject the null hypothesis of no cointegration at $5 \%$ level of significance. So, there is existence of a long-run linkages between the economic variables and the stock indices in technology sector. The long run cointegrating linkages expressed in equation below is thus given as:

\section{TECH $=139.9215$ - 0.011336GOLD - 0.419823OIL - 20.09978XCHNGE}

Based on the equation above, all economic variables show negative linkages towards TECH. A $1 \%$ increase in GOLD, reduce technology stock return by $0.01 \%$ while a $1 \%$ increase in OIL reduce stock by $0.42 \%$. In the long run, return of technology stock decreases by $20.1 \%$ due to decreases in XCHNGE by $1 \%$. The analysis from this study has revealed that most of the sectoral indices in Bursa Malaysia have not cointegrated in the long run with the three macroeconomic variables (gold price, oil price and exchange rate). Results in Table 3, clearly highlighted this scenario and the only sectoral indices that found to have long run cointegration linkages with economic variables is Technology (significant at $5 \%$ level)

\section{VECM and VAR Causality Test VECM Causality}

Result from the VECM for technology sector presented in table 4 below. It shows that none of the economic variable have short run linkages to the sector indices. However, the error correction mechanism and cointegration theory suggest that the technology sector indices and the economic variables have long-run linkages where short-run disequilibrium is corrected. The coefficient of the ECT indicates speed of adjustment towards long-run equilibrium. As expected, ECT is significance at 15 level and show negative sign. It suggest that following a shock to the stock market in the shortrun, deviation from long-run equilibrium is corrected by $18.14 \%$ every month and take approximately 5 to 6 months for all disequilibrium to be corrected and the series eventually returned fully to its long-run equilibrium.

\begin{tabular}{|l|l|l|l|l|}
\hline \multirow{3}{*}{ Sectoral Indices } & \multicolumn{2}{|l|}{ Economic Indicators } & \multirow{2}{*}{ Long Run } \\
\cline { 2 - 5 } & Short Run & \\
\cline { 2 - 5 } & Gold Price & Oil Price & Exchange Rate & Ect \\
\hline \multirow{2}{*}{ Technology } & 1.844551 & 0.696577 & 1.60605 & -0.181389 \\
\cline { 2 - 5 } & {$[0.3976]$} & {$[0.7059]$} & {$[0.448]$} & {$[0.0000]^{* * *}$} \\
\hline
\end{tabular}

Table 4: VECM Causality Test Result

\section{VAR Causality}

For other sectors' indices, VAR Causality test has been applied as they are not cointegrated in the long run. The VAR Causality result in Table 5 below shows the short-run linkages between economic variables and sectors' indices at $10 \%, 5 \%$ and $1 \%$ levels of significance. Gold price and exchange rate appear to have short-run causality towards financial sector indices at $1 \%$ level of significance. In the meantime, exchange rate seem to granger cause industrial sector indices while gold price granger cause consumer product sector indices in short-run. Plantation sector indices impacted by gold price and exchange rate at $5 \%$ level of significance. Exchange rate also appear to have short-run causality towards properties sector indices and tin \& mining sector indices at $1 \%$ and $5 \%$ level of significance, respectively. Lastly, trade \& service sector indices, gold price indicates causality at $1 \%$ level while exchange rate statistically significance at $5 \%$. 


\begin{tabular}{|c|c|c|c|}
\hline \multirow{2}{*}{ Sectoral Indices } & \multicolumn{3}{|c|}{ Economic Indicators } \\
\hline & Gold Price & Oil Price & Exchange Rate \\
\hline \multirow{2}{*}{ Financial } & 9.569275 & 1.779232 & 14.32599 \\
\hline & {$[0.0084]^{* * *}$} & {$[0.4108]$} & {$[0.0008]^{* * *}$} \\
\hline \multirow{2}{*}{ Construction } & 4.807309 & 2.096949 & 3.418332 \\
\hline & {$[0.0904]^{*}$} & {$[0.3505]$} & {$[0.181]$} \\
\hline \multirow{2}{*}{ Industrial } & 2.998881 & 1.146201 & 11.39033 \\
\hline & {$[0.2233]$} & {$[0.5638]$} & {$[0.0034]^{* * *}$} \\
\hline \multirow{2}{*}{ Consumer Product } & 18.89343 & 3.052934 & 4.306954 \\
\hline & {$[0.0001]^{\star \star *}$} & {$[0.2173]$} & {$[0.1161]$} \\
\hline \multirow{2}{*}{ Industrial Product } & 9.350823 & 1.921824 & 2.775284 \\
\hline & {$[0.0093]^{* * *}$} & {$[0.3825]$} & $\begin{array}{l}{[0.2497]} \\
\end{array}$ \\
\hline \multirow{2}{*}{ Plantation } & 7.459718 & 2.815782 & 7.884758 \\
\hline & {$[0.024]^{\star *}$} & {$[0.2447]$} & {$[0.0194]^{* *}$} \\
\hline \multirow{2}{*}{ Properties } & 2.153648 & 2.622194 & 12.9414 \\
\hline & {$[0.3407]$} & {$[0.2695]$} & {$[0.0015]^{* * *}$} \\
\hline \multirow{2}{*}{ Tin \& Mining } & 3.257468 & 2.334054 & 6.25617 \\
\hline & {$[0.1962]$} & {$[0.3113]$} & {$[0.0438]^{* *}$} \\
\hline \multirow{2}{*}{ Trade \& Service } & 15.21668 & 3.651159 & 7.338608 \\
\hline & {$[0.0005]^{* * *}$} & {$[0.1611]$} & {$[0.0255]^{* *}$} \\
\hline
\end{tabular}

Table 5: VAR Causality Test Result

\section{Conclusions and Future Research}

This paper examines the linkages between sectoral indices and selected macroeconomic variables based on time series analysis. Both short-run and long-run causality linkages between sectoral indices and macroeconomic variables are analyzed. The findings have ascertained the fact that in both long run and short run, the linkages between the three selected macroeconomics variables and sectoral indices in Bursa Malaysia have been observed. In the long-run, it suggests that the technology sector indices and the economic variables have long-run linkages. In the short run, it indicates that any movement in gold price and exchange rate will give impact to financial sector indices as well as plantation and trade \& services. In construction sector, none of the variables is found to have significant cause towards sectoral indices Meanwhile, there are some limitations in this study that require further improvement by future researchers particularly on the selection of the macroeconomic variables. It is recommended that future researches could explore macroeconomic variables other than gold price, oil price and exchange rate such as trade balance, money supply, Federal Reserve as well as some other pertinent variables so that more comprehensive findings could be obtained in addressing the overall scenario of the relationship between the macroeconomic perspective and stock market movement. The output from the study is expected to provide more information in terms of the relationship between macroeconomic variables and stock market conditions. Furthermore, this study is focusing the sectoral indices in the Malaysian stock market and it is suggested that future research to focus other countries' sectoral stock market indices so that the findings will become more generalized. As a conclusion, the findings from this study are considered important in providing information to the investors in establishing the well-diversified portfolio investment based on various sectors. 


\section{References}

Asaolu, T. O., and Ogunmuyiwa, M. S. (2011). An econometric analysis of the impact of macroeconomic variables on stock market movement in Nigeria.Asian Journal of Business Management, 3(1), 72-78.

Baur, D. G., and Lucey, B. M. (2010). Is gold a hedge or a safe haven? An analysis of stocks, bonds and gold.Financial Review, 45(2), 217-229.

Fatima, T., and Bashir, A. (2014). Oil Price and Stock Market Fluctuations: Emerging Markets (A Comparative Study of Pakistan and China). International Review of Management and Business Research, 3(4), 1958-1976.

Fedorova, E. A., and Pankratov, K. A. (2010). Influence of macroeconomic factors on the Russian stock market. Studies on Russian Economic Development, 21(2), 165-168.

Gencer, H. G., and Demiralay, S. (2014). Shock and Volatility Spillovers between Oil Prices and Turkish Sector Returns.International Journal of Economics and Finance, 6(2), 174-180.

Hosseini, S. M., Ahmad, Z., and Lai, Y. W. (2011).The role of macroeconomic variables on stock market index in China and India. International Journal of Economics and Finance, 3(6), 233-243.

Ibrahim, M. H. (2000). Cointegration and Granger Causality Tests of Stock Price and Exchange Rate Interactions in Malaysia, ASEAN Economic Bulletin, 17, 1: 36-47.

Jaafar, P., \& Ismail, A. (2009).Dynamic relationship between sector-specific indices and macroeconomic fundamentals, Malaysian Accounting Review, 8(1), 81-100.

Joshi, P., and Giri, A. K. (2013). An empirical analysis of the linkages between stock market indices and macro-economic variables: Evidences from India. International Academic Research Journal of Economics and Finance, 2(1), 17-24.

Kalyanaraman, L., and Al Tuwajri, B. (2014). Macroeconomic forces and stock prices: some empirical evidence from Saudi Arabia. International Journal of Financial Research, 5(1), p81.

Khan, M. N., andZaman, S. (2011). Impact of Macroeconomic Variables on Stock Prices: Empirical Evidence from Karachi Stock Exchange, Pakistan. International Journal of Operational Management, Marketing and Services, 1(1), 78-84.

Masih, R., Peters, S., and De Mello, L. (2011). Oil price volatility and stock price fluctuations in an emerging market: evidence from South Korea. Energy Economics, 33(5), 975-986.

Maysami, R. C., Howe, L. C., andHamzah, M. A. (2004). Linkages between macroeconomic variables and stock market indices: cointegration evidence from stock exchange of Singapore's all-S sector indices. JurnalPengurusan, 24(1), 47-77.

Mohamed, S., Ali, A., Azman, K. and Abdullah, N. (2011). Malaysian Sectoral Indices VS Macroeconomic Factors, Any Correlation?: Evidence From Malaysia, International Proceedings of Economics Development and Research, 4, 493-497.

Park, J., and Ratti, R. A. (2008).Oil price shocks and stock markets in the US and 13 European countries.Energy Economics, 30(5), 2587-2608.

Phylaktis, Kate, Ravazzolo and Fabiola (2005). Stock Prices and Exchange Rate Dynamics, Journal of International Money and Finance, 24: 1031-1053.

Singh, G. (2015). The Linkages Between Exchange Rate and Stock Price in India: An Empirical Study. IUP Journal of Financial Risk Management, 12(2), 18-29.

Wongbangpo, P., and Sharma, S. C. (2002). Stock market and macroeconomic fundamental dynamic interactions: ASEAN-5 countries. Journal of Asian Economics, 13(1), 27-51.

Zhao, H. (2010). Dynamic linkages between exchange rate and stock price: Evidence from China. Research in International Business and Finance, 24(2), 103-112. 